\title{
Araneae communities associated with the canopies of chestnut trees in the northeastern part of Portugal: The influence of soil management practices
}

\author{
JACINTO BENHADI-MARIN ${ }^{1}$, José Alberto PEREIRA², José-Antonio BARRIENTOS ${ }^{3}$, Albino BENTO² \\ and SÓNIA A.P. SANTOS ${ }^{2 *}$ \\ ${ }^{1}$ Departamento de Biodiversidad y Gestión Ambiental, Área de Zoología, Universidad de León, Campus de Vegazana, 24071 León, \\ Spain \\ ${ }^{2}$ Mountain Research Center (CIMO), School of Agriculture, Polytechnic Institute of Bragança, Campus de Santa Apolónia, \\ Apt. 1172, 5301-855 Bragança, Portugal \\ ${ }^{3}$ Unidad de Zoología, Facultad de Biociencias, Universidad Autónoma de Barcelona, 08193 Bellaterra, Barcelona, Spain
}

Key words. Araneidae, Philodromidae, Thomisidae, Castanea sativa, diversity, guilds, grazing, pest control, tilled, untilled

\begin{abstract}
Chestnut (Castanea sativa Mill.) is one of the economically more important trees in the north of Portugal. Spiders, as generalist predators, are potential controlling agents of pests, yet the composition of the community of spiders associated with this crop is only poorly known. The objective of this study was to determine the spider communities in the canopies of chestnut trees subject to three different soil management practices in northeastern Portugal. Three chestnut groves each subject to a different agricultural practice (grazed, tilled or untilled) were studied in 2008 and 2009. The Araneae communities were sampled by beating the branches and the individuals collected were identified to family and species when possible. To investigate the structure of the spider community in each grove the abundance and family richness of spiders were calculated and compared between managements. In total, 4172 spiders were collected and, in both years, the three most abundant families were Araneidae, Philodromidae and Linyphiidae. In 2008 , there was a greater abundance of spiders in the grazed, followed by the tilled and untilled groves, but no significant differences among groves. However, in 2009 there was a greater abundance of spiders in the tilled grove, followed by grazed and untilled groves and the differences between the untilled and the other two groves were significant. Araniella, Oxyopes and Anyphaena were the most abundant genera in the three groves. This study showed that soil management may influence the diversity of spiders, but the effects were weak and not consistent between years. The reduction or absence of a suitable habitat for spiders under the trees in the tilled treatment might have resulted in the spiders migrating up into the canopy. However, based on the weak effects on spider abundance recorded and its potentially adverse effects on soils, tillage is not recommended for managing the incidence of pests in chestnut groves.
\end{abstract}

\section{INTRODUCTION}

Chestnut (Castanea sativa Mill.) is traditionally cultivated tree in the north of Portugal because it is well adapted to growing in the local soils (moderately deep and well drained sandy-loam soils) and of its social and economical importance (Monteiro, 2000). The main pests of this crop are tortricids (Cydia spp.) and curculionids (Curculio spp.), which can cause losses of up to $50 \%$ of the seed production (Assunção, 1997; Paparatti \& Speranza, 2005; Aguin-Pombo et al., 2008). Furthermore, other phytophagous species such as mites, aphids, psyllids and diaspidids are frequently recorded in chestnut trees (A. Bento, unpubl. results). Despite high yield losses, it is not possible to use chemical control due to the lack of accredited products for use against pests of chestnut in Portugal (Oliveira, 2011) and thus there is a need to use biological control agents against these pests. Spiders are generalist predators, which catch mainly insects of a wide range of sizes and may control the abundance of pests.

Several studies have shown that spiders are important natural enemies of pests in agroecosystems. These predator-prey interactions are well documented by direct observations on spiders hunting and feeding (e.g. Sunderland et al., 1986; Ghavami, 2008; Monzó et al., 2009; Oelbermann \& Scheu, 2009), morphological measurements (e.g. Nentwig \& Wissel, 1986), serological (e.g. Nakamura \& Nakamura, 1977; Morris et al., 1999) and molecular gut-content analysis (Greenstone \& Shufran, 2003) and by studies of the feeding behaviour and functional responses of spiders fed different types of prey (Samu \& Bíró, 1993; Harwood et al., 2009). The potential efficiency of spiders as biological control agents can be evaluated by a clear characterization of the spider community associated with each crop. For chestnut, there is also a need for information on whether the structure of the spider community can also be affected by management practices. According to Prieto-Benítez \& Méndez (2011), the management of ground vegetation by using herbicides, cutting, tillage and grazing negatively affected the diversity of spiders. Tillage and grazing are common practices in chestnut groves. The former is used to control weeds and conserve soil water (Martins et al., 2005) by creating a bare soil surface. Usually, the effect of tillage

\footnotetext{
* Corresponding author; e-mail: saps@ipb.pt
} 
on invertebrates depends on its intensity and frequency (Edwards, 1977) and Rodríguez et al. (2006) record a lower abundance of Araneae in tilled than in untilled corn crops. On the other hand, grazing by livestock along with the associated effects of trampling and defecating may result in botanically rich and structurally diverse habitats (Dennis et al., 1998; Cole et al., 2010). Consequently, moderate grazing regimes can promote habitat heterogeneity that supports richer arthropod communities as is documented for large carabids, predatory larvae of Coleoptera and lycosids (Blake et al., 1994; Cole et al., 2005). Changes in arthropod soil communities could also affect the communities in canopies of trees, especially if spiders in the soil community climb up the trunks of trees. Therefore, the objective of this study was to determine the spider communities in the canopies of chestnut trees growing under different soil management practices in the Trás-os-Montes region of northeastern Portugal.

\section{MATERIAL AND METHODS}

\section{Study sites}

Field sites located in three chestnut groves near Bragança (northeastern Portugal), Rossas $\left(41^{\circ} 39^{\prime} 41^{\prime \prime} \mathrm{N}, 06^{\circ} 50^{\prime} 54^{\prime \prime} \mathrm{W}\right)$, Oleiros $1 \quad\left(41^{\circ} 50^{\prime} 60^{\prime \prime} \mathrm{N}, 0^{\circ} 49^{\prime} 52^{\prime \prime} \mathrm{W}\right)$ and Oleiros 2 $\left(41^{\circ} 50^{\prime} 50^{\prime \prime} \mathrm{N}, 06^{\circ} 49^{\prime} 49^{\prime \prime} \mathrm{W}\right)$ were studied during two cropping seasons, 2008 and 2009. The sampling took place between July and October and the actual timing depended on the phenology of the crop, i.e., chestnut is a deciduous tree the buds of which usually burst before the end of May - beginning of June. Rossas occupies an area of about 50 ha and the herbaceous vegetation growing there had been maintained and managed by sheep grazing for the last 20 years. Oleiros 1 occupies an area of about 2.5 ha and the natural vegetation was maintained by cutting it once a year at the end of October (before harvest). Oleiros 2 occupies an area of 3 ha and the soil there was ploughed two or three times a year to control weeds. In all three groves there were no phytosanitary treatments and no irrigation. In this paper, Rossas is referred to as grazed, Oleiros 1 as untilled and Oleiros 2 as tilled.

\section{Sampling of Araneae}

A central area of 2 ha was established in every grove and the Araneae communities there were sampled by beating the branches of trees at fortnightly intervals. Each branch was beaten twice over a rectangular piece of cloth $(0.6 \mathrm{~m} \times 0.5 \mathrm{~m})$ and five samples were collected on each date from each grove, and each sample was made up of the combined results of the beating of 10 branches, one branch per tree. At each sampling period, trees were selected randomly. The branches at a height range of between 150 and $180 \mathrm{~cm}$ were randomly selected from a total number of 50 trees per grove. All the spiders collected were frozen, sorted, counted, identified using a binocular stereomicroscope and preserved in $70 \%$ ethanol to avoid desiccation. The individuals were identified using the keys of Nentwig et al. (2011), Roberts $(1985,1987)$ and Simon (1914-1937) and followed the nomenclatural system of Platnick (2012). Immatures were included in the analysis.

\section{Data analysis}

Abundance data were evaluated for normality and homogeneity of variance using the Kolmogorov-Smirnov and Bartlett's tests, respectively, and when necessary, transformed by using $\log (\mathrm{x}+1)$ to normalize the data.
One way ANOVA was used to compare total abundance of Araneae and the abundance of the three most common families. Significance levels for all analyses were set at $\mathrm{P}<0.05$.

Family richness (S), Simpson's diversity index (D) and evenness $\left(\mathrm{E}_{1 / \mathrm{D}}\right)$ were calculated for each grove. Simpson's diversity index was calculated as $1 / \mathrm{D}$, using the equation:

$$
1 / D=1 / \sum_{i=1}^{s} p_{i}^{2}
$$

where $p_{\mathrm{i}}{ }^{2}$ is the proportion of individuals of the $i^{\text {th }}$ family and $\mathrm{S}$ the total number of families. The minimum value of $1 / \mathrm{D}$ is 1 which is reached when the community has only a single species and the maximum is $\mathrm{S}$, which is reached when all the species in a community are equally abundant (Magurran, 2004). This index takes into account the number of species present as well as the abundance of each species and provides a good estimate of diversity based on relatively small sample sizes and ranks assemblages consistently, i.e., an increase in the index is associated with an increase in diversity. Evenness expresses the dominance and was calculated as

$$
E_{1 / D}=(1 / D) / S
$$

$\mathrm{E}_{1 / \mathrm{D}}$ is defined between 0 and 1 , where 1 represents a community with perfect evenness, and decreases towards zero as the relative abundances of the species diverge from evenness (Magurran, 2004).

Community composition was investigated by plotting rankabundance curves for each grove, with the relative abundance of each family as its index of abundance. The relative abundance for the most common species is plotted first, followed by the next most common species until the array is completed by the rarest species (Magurran, 2004). Abundance was tested against the predicted distribution by geometric-, log-series- log-normaland broken stick models. The difference between observed and expected values was tested using $\chi^{2}$ tests which give the probability of fit of each distribution model and the observed Araneae abundance.

\section{RESULTS}

During the two years, a total of 4172 spiders were collected, of which 44 were adults $(1.05 \%)$ and 4128 immature $(98.95 \%)$. In 2008 , there was a greater abundance of spiders in the grazed grove followed by the tilled and untilled groves (Table 1). The four most abundant families in the grazed grove were Araneidae (22.53\%), Philodromidae $(22.32 \%)$, Linyphiidae $(13.37 \%)$ and Thomisidae (10.63\%), while Philodromidae, Araneidae and Linyphiidae dominated the community in the other two groves, and Thomisidae and Theridiidae were the fourth most common families in tilled and untilled groves, respectively. Despite these variations, there were no significant differences in the total abundance of spiders in each grove $\left(\mathrm{F}_{2,112}=0.92, \mathrm{P}=0.40\right)$ in 2008. The genera Araniella, Oxyopes and Anyphaena were the most abundant in the three groves studied. The family Dictynidae occurred in increasing abundance from tilled to grazed groves.

In 2009, there was a greater abundance of spiders in the tilled grove, followed by grazed and untilled groves (Table 2). Philodromidae, Araneidae and Thomisidae were the three most abundant families in all the groves studied. However, the fourth most abundant family varied from Dictynidae in grazed, Theridiidae in untilled and 
TABLE 1. Guilds at the level of families, total number of Araneae $(\mathrm{N})$, number of samples in which the species occurred $(f)$, occurrence $(\mathrm{O} \%)$, family richness, Simpson index $(1 / \mathrm{D})$ and evenness $\left(\mathrm{E}_{1 / \mathrm{D}}\right)$ of families in all the samples collected from the canopies of the chestnut trees in each of the three types of grove studied in 2008 .

\begin{tabular}{|c|c|c|c|c|c|c|c|c|c|c|}
\hline \multirow{2}{*}{ Family / Species } & \multirow{2}{*}{ Guild } & \multicolumn{3}{|c|}{ Tilled $(n=39)$} & \multicolumn{3}{|c|}{ Untilled $(\mathrm{n}=39)$} & \multicolumn{3}{|c|}{ Grazed $(n=37)$} \\
\hline & & $\mathrm{N}$ & $f$ & $\mathrm{O}(\%)$ & $\mathrm{N}$ & $f$ & $\mathrm{O}(\%)$ & $\mathrm{N}$ & $f$ & $\mathrm{O}(\%)$ \\
\hline ANYPHAENIDAE & 6 & & & & & & & & & \\
\hline Anyphaena numida Simon, 1897 & & 2 & 2 & 5.13 & 3 & 3 & 7.69 & 5 & 4 & 10.81 \\
\hline Anyphaena spp. & & 23 & 15 & 38.46 & 6 & 4 & 10.26 & 16 & 10 & 27.03 \\
\hline Subtotal & & 25 & 17 & 43.59 & 9 & 7 & 17.95 & 21 & 14 & 37.84 \\
\hline ARANEIDAE & 2 & & & & & & & & & \\
\hline Araniella spp. & & 172 & 28 & 71.79 & 140 & 25 & 64.10 & 182 & 24 & 64.86 \\
\hline Mangora acalypha (Walckenaer, 1802) & & 4 & 3 & 7.69 & 0 & 0 & 0.00 & 1 & 1 & 2.70 \\
\hline Araneidae unid. immature & & 30 & 10 & 25.64 & 39 & 13 & 33.33 & 31 & 9 & 24.32 \\
\hline Subtotal & & 206 & 41 & 105.13 & 179 & 38 & 97.44 & 214 & 34 & 91.89 \\
\hline Clubionidae & 6 & & & & & & & & & \\
\hline Clubiona sp. & & 1 & 1 & 2.56 & 1 & 1 & 2.56 & 0 & 0 & 0.00 \\
\hline Subtotal & & 1 & 1 & 2.56 & 1 & 1 & 2.56 & 0 & 0 & 0.00 \\
\hline DictyNidAE & 3 & & & & & & & & & \\
\hline Dictynidae unid. immature & & 45 & 20 & 51.28 & 57 & 23 & 58.97 & 95 & 24 & 64.86 \\
\hline Subtotal & & 45 & 20 & 51.28 & 57 & 23 & 58.97 & 95 & 24 & 64.86 \\
\hline GNAPHOSIDAE & 7 & & & & & & & & & \\
\hline Gnaphosidae unid. immature & & 1 & 1 & 2.56 & 1 & 1 & 2.56 & 1 & 1 & 2.70 \\
\hline Subtotal & & 1 & 1 & 2.56 & 1 & 1 & 2.56 & 1 & 1 & 2.70 \\
\hline LINYPHIIDAE & 4 & & & & & & & & & \\
\hline Meioneta fuscipalpa (C.L. Koch, 1836) & & 0 & 0 & 0.00 & 0 & 0 & 0.00 & 1 & 1 & 2.70 \\
\hline Meioneta rurestris (C.L. Koch, 1836) & & 3 & 3 & 7.69 & 0 & 0 & 0.00 & 0 & 0 & 0.00 \\
\hline Tenuiphantes tenuis (Blackwall, 1852) & & 2 & 2 & 5.13 & 0 & 0 & 0.00 & 0 & 0 & 0.00 \\
\hline Tenuiphantes sp. & & 0 & 0 & 0.00 & 1 & 1 & 2.56 & 0 & 0 & 0.00 \\
\hline Typhochrestus digitatus (O. P.-Cambridge, 1872) & & 0 & 0 & 0.00 & 2 & 1 & 2.56 & 0 & 0 & 0.00 \\
\hline Linyphiidae unid. immature & & 91 & 29 & 74.36 & 96 & 30 & 76.92 & 126 & 34 & 91.89 \\
\hline Subtotal & & 96 & 34 & 87.18 & 99 & 32 & 82.05 & 127 & 35 & 94.59 \\
\hline MiturgidAe & 6 & & & & & & & & & \\
\hline Cheiracanthium sp. & & 1 & 1 & 2.56 & 0 & 0 & 0.00 & 0 & 0 & 0.00 \\
\hline Subtotal & & 1 & 1 & 2.56 & 0 & 0 & 0.00 & 0 & 0 & 0.00 \\
\hline OXYOPIDAE & 5 & & & & & & & & & \\
\hline Oxyopes spp. & & 34 & 18 & 46.15 & 8 & 7 & 17.95 & 44 & 16 & 43.24 \\
\hline Subtotal & & 34 & 18 & 46.15 & 8 & 7 & 17.95 & 44 & 16 & 43.24 \\
\hline PHILODROMIDAE & 1 & & & & & & & & & \\
\hline Philodromus cespitum (Walckenaer, 1802) & & 1 & 1 & 2.56 & 0 & 0 & 0.00 & 0 & 0 & 0.00 \\
\hline Philodromus praedatus O. P.-Cambridge, 1871 & & 3 & 2 & 5.13 & 1 & 1 & 2.56 & 1 & 1 & 2.70 \\
\hline Philodromidae unid. immature & & 207 & 37 & 94.87 & 184 & 35 & 89.74 & 211 & 35 & 94.59 \\
\hline Subtotal & & 211 & 40 & 102.56 & 185 & 36 & 92.31 & 212 & 36 & 97.30 \\
\hline SAlticidae & 5 & & & & & & & & & \\
\hline Icius subinermis Simon, 1937 & & 0 & 0 & 0.00 & 1 & 1 & 2.56 & 0 & 0 & 0.00 \\
\hline Macaroeris nidicolens (Walckenaer, 1802) & & 0 & 0 & 0.00 & 2 & 2 & 5.13 & 0 & 0 & 0.00 \\
\hline Salticidae unid. immature & & 15 & 13 & 33.33 & 21 & 13 & 33.33 & 16 & 11 & 29.73 \\
\hline Subtotal & & 15 & 13 & 33.33 & 24 & 16 & 41.03 & 16 & 11 & 29.73 \\
\hline THERIDIIDAE & 3 & & & & & & & & & \\
\hline Enoplogntha ovata (Clerck, 1757) & & 1 & 1 & 2.56 & 0 & 0 & 0.00 & 0 & 0 & 0.00 \\
\hline Theridion hannoniae Denis, 1944 & & 0 & 0 & 0.00 & 0 & 0 & 0.00 & 1 & 1 & 2.70 \\
\hline Theridion sp. 1 & & 1 & 1 & 2.56 & 0 & 0 & 0.00 & 0 & 0 & 0.00 \\
\hline Theridiidae unid. immature & & 42 & 19 & 48.72 & 81 & 23 & 58.97 & 59 & 18 & 48.65 \\
\hline Subtotal & & 44 & 21 & 53.85 & 81 & 23 & 58.97 & 60 & 19 & 51.35 \\
\hline THOMISIDAE & 1 & & & & & & & & & \\
\hline Synema globosum (Fabricius, 1775) & & 10 & 9 & 23.08 & 3 & 3 & 7.69 & 4 & 4 & 10.81 \\
\hline Thomisus onustus Walckenaer, 1805 & & 2 & 2 & 5.13 & 0 & 0 & 0.00 & 1 & 1 & 2.70 \\
\hline Thomisidae unid. immature & & 79 & 25 & 64.10 & 73 & 24 & 61.54 & 96 & 21 & 56.76 \\
\hline Subtotal & & 91 & 36 & 92.31 & 76 & 27 & 69.23 & 101 & 26 & 70.27 \\
\hline ULOBORIDAE & 2 & & & & & & & & & \\
\hline Uloborus sp. & & 2 & 2 & 5.13 & 0 & 0 & 0.00 & 0 & 0 & 0.00 \\
\hline Subtotal & & 2 & 2 & 5.13 & 0 & 0 & 0.00 & 0 & 0 & 0.00 \\
\hline Araneae unid. immature & & 64 & & & 67 & & & 59 & & \\
\hline Total & & 836 & & & 787 & & & 950 & & \\
\hline Richness - S (families) & & 13 & & & 11 & & & 10 & & \\
\hline Simpson index - 1/D (families) & & 5.43 & & & 5.65 & & & 6.03 & & \\
\hline Evenness $-\mathrm{E}_{1 / \mathrm{D}}$ (families $)$ & & 0.42 & & & 0.51 & & & 0.60 & & \\
\hline
\end{tabular}

Codes for the guilds: 1 - ambushers, 2 - orb weavers, 3 - space web builders, 4 - wandering sheet/tangle weavers, 5 - stalkers, 6 - foliage runners and 7 - ground runners. 
TABLE 2. Guilds at the level of families, total number of Araneae $(\mathrm{N})$, number of samples in which the species occurred $(f)$, occurrence $(\mathrm{O} \%)$, family richness $(\mathrm{S})$, Simpson index $(1 / \mathrm{D})$ and evenness $\left(\mathrm{E}_{1 / \mathrm{D}}\right)$ of families in all the samples collected from the canopies of the chestnut trees in the three types of grove studied in 2009.

\begin{tabular}{|c|c|c|c|c|c|c|c|c|c|c|c|}
\hline \multirow{2}{*}{\multicolumn{2}{|c|}{ Family / Species }} & \multirow{2}{*}{ Guild } & \multicolumn{3}{|c|}{ Tilled $(n=39)$} & \multicolumn{3}{|c|}{ Untilled $(\mathrm{n}=38)$} & \multicolumn{3}{|c|}{ Grazed $(n=40)$} \\
\hline & & & $\mathrm{N}$ & $f$ & $\mathrm{O}(\%)$ & $\mathrm{N}$ & $f$ & $\mathrm{O}(\%)$ & $\mathrm{N}$ & $f$ & $\mathrm{O}(\%)$ \\
\hline ANYPHAENIDAE & & 6 & & & & & & & & & \\
\hline Anyphaena numida Simon, 1897 & & & 2 & 2 & 5.13 & 4 & 3 & 7.89 & 1 & 1 & 2.50 \\
\hline Anyphaena sp. & & & 16 & 11 & 28.21 & 8 & 8 & 21.05 & 16 & 9 & 22.50 \\
\hline & Subtotal & & 18 & 13 & 33.33 & 12 & 11 & 28.95 & 17 & 10 & 25.00 \\
\hline ARANEIDAE & & 2 & & & & & & & & & \\
\hline Araneus diadematus Clerck, 1757 & & & 1 & 1 & 2.56 & 0 & 0 & 0.00 & 0 & 0 & 0.00 \\
\hline Araniella cucurbitina (Clerck, 1757) & & & 1 & 1 & 2.56 & 2 & 2 & 5.26 & 0 & 0 & 0.00 \\
\hline Araniella sp. & & & 0 & 0 & 0.00 & 48 & 14 & 36.84 & 82 & 33 & 82.50 \\
\hline Araneidae unid. immature & & & 120 & 34 & 87.18 & 49 & 22 & 57.89 & 13 & 11 & 27.50 \\
\hline & Subtotal & & 122 & 36 & 92.31 & 99 & 38 & 100.00 & 95 & 44 & 110.00 \\
\hline Clubionidae & & 6 & & & & & & & & & \\
\hline Clubiona sp. & & & 1 & 1 & 2.56 & 4 & 3 & 7.89 & 2 & 2 & 5.00 \\
\hline & Subtotal & & 1 & 1 & 2.56 & 4 & 3 & 7.89 & 2 & 2 & 5.00 \\
\hline DictyNidAE & & 3 & & & & & & & & & \\
\hline Dictynidae unid. immature & & & 32 & 21 & 53.85 & 22 & 14 & 36.84 & 50 & 21 & 52.50 \\
\hline & Subtotal & & 32 & 21 & 53.85 & 22 & 14 & 36.84 & 50 & 21 & 52.50 \\
\hline GNAPHOSIDAE & & 7 & & & & & & & & & \\
\hline Gnaphosidae unid. immature & & & 0 & 0 & 0.00 & 0 & 0 & 0.00 & 1 & 1 & 2.50 \\
\hline & Subtotal & & 0 & 0 & 0.00 & 0 & 0 & 0.00 & 1 & 1 & 2.50 \\
\hline LINYPHIIDAE & & 4 & & & & & & & & & \\
\hline Linyphiidae unid. immature & & & 26 & 20 & 51.28 & 23 & 15 & 39.47 & 18 & 16 & 40.00 \\
\hline & Subtotal & & 26 & 20 & 51.28 & 23 & 15 & 39.47 & 18 & 16 & 40.00 \\
\hline OXYOPIDAE & & 5 & & & & & & & & & \\
\hline Oxyopes sp. & & & 26 & 14 & 35.90 & 16 & 10 & 26.32 & 37 & 21 & 52.50 \\
\hline & Subtotal & & 26 & 14 & 35.90 & 16 & 10 & 26.32 & 37 & 21 & 52.50 \\
\hline PhILODROMIDAE & & 1 & & & & & & & & & \\
\hline Philodromus buxi Simon, 1884 & & & 0 & 0 & 0.00 & 0 & 0 & 0.00 & 1 & 1 & 2.50 \\
\hline Philodromidae unid. immature & & & 165 & 34 & 87.18 & 131 & 33 & 86.84 & 181 & 38 & 95.00 \\
\hline & Subtotal & & 165 & 34 & 87.18 & 131 & 33 & 86.84 & 182 & 39 & 97.50 \\
\hline SAlticidae & & 5 & & & & & & & & & \\
\hline Salticidae unid. immature & & & 16 & 14 & 35.90 & 24 & 14 & 36.84 & 19 & 14 & 35.00 \\
\hline & Subtotal & & 16 & 14 & 35.90 & 24 & 14 & 36.84 & 19 & 14 & 35.00 \\
\hline SpARASSIDAE & & 6 & & & & & & & & & \\
\hline Sparassidae unid. immature & & & 0 & 0 & 0.00 & 0 & 0 & 0.00 & 3 & 2 & 5.00 \\
\hline & Subtotal & & 0 & 0 & 0.00 & 0 & 0 & 0.00 & 3 & 2 & 5.00 \\
\hline THERIDIIDAE & & 3 & & & & & & & & & \\
\hline Parasteatoda tepidariorum (C.L. Koch, & 1841) & & 1 & 1 & 2.56 & 0 & 0 & 0.00 & 0 & 0 & 0.00 \\
\hline Platnickina tincta (Walckenaer, 1802) & & & 1 & 1 & 2.56 & 0 & 0 & 0.00 & 0 & 0 & 0.00 \\
\hline Theridiidae unid. immature & & & 34 & 24 & 61.54 & 19 & 14 & 36.84 & 29 & 18 & 45.00 \\
\hline & Subtotal & & 36 & 26 & 66.67 & 19 & 14 & 36.84 & 29 & 18 & 45.00 \\
\hline THOMISIDAE & & 1 & & & & & & & & & \\
\hline Thomisidae unid. immature & & & 80 & 25 & 64.10 & 27 & 20 & 52.63 & 51 & 26 & 65.00 \\
\hline & Subtotal & & 80 & 25 & 64.10 & 27 & 20 & 52.63 & 51 & 26 & 65.00 \\
\hline Titanoecidae & & 8 & & & & & & & & & \\
\hline Titanoecidae unid. immature & & & 0 & 0 & 0.00 & 1 & 1 & 2.63 & 0 & 0 & 0.00 \\
\hline & Subtotal & & 0 & 0 & 0.00 & 1 & 1 & 2.63 & 0 & 0 & 0.00 \\
\hline ULOBORIDAE & & 2 & & & & & & & & & \\
\hline Uloboridae unid. immature & & & 2 & 2 & 5.13 & 1 & 1 & 2.63 & 0 & 0 & 0.00 \\
\hline & Subtotal & & 2 & 2 & 5.13 & 1 & 1 & 2.63 & 0 & 0 & 0.00 \\
\hline Araneae unid. immature & & & 58 & & & 63 & & & 71 & & \\
\hline & Total & & 582 & & & 442 & & & 575 & & \\
\hline & (families) & & 11 & & & 12 & & & 12 & & \\
\hline $1 / \mathrm{D}$ & families) & & 5.25 & & & 4.83 & & & 5.08 & & \\
\hline $\mathrm{E}_{1 / \mathrm{D}}$ & (families) & & 0.48 & & & 0.40 & & & 0.42 & & \\
\hline
\end{tabular}

Code for the guilds: 1 - ambushers, 2 - orb weavers, 3 - space web builders, 4 - wandering sheet/tangle weavers, 5 - stalkers, 6 - foliage runners, 7 - ground runners and 8 - sheet web builders. 

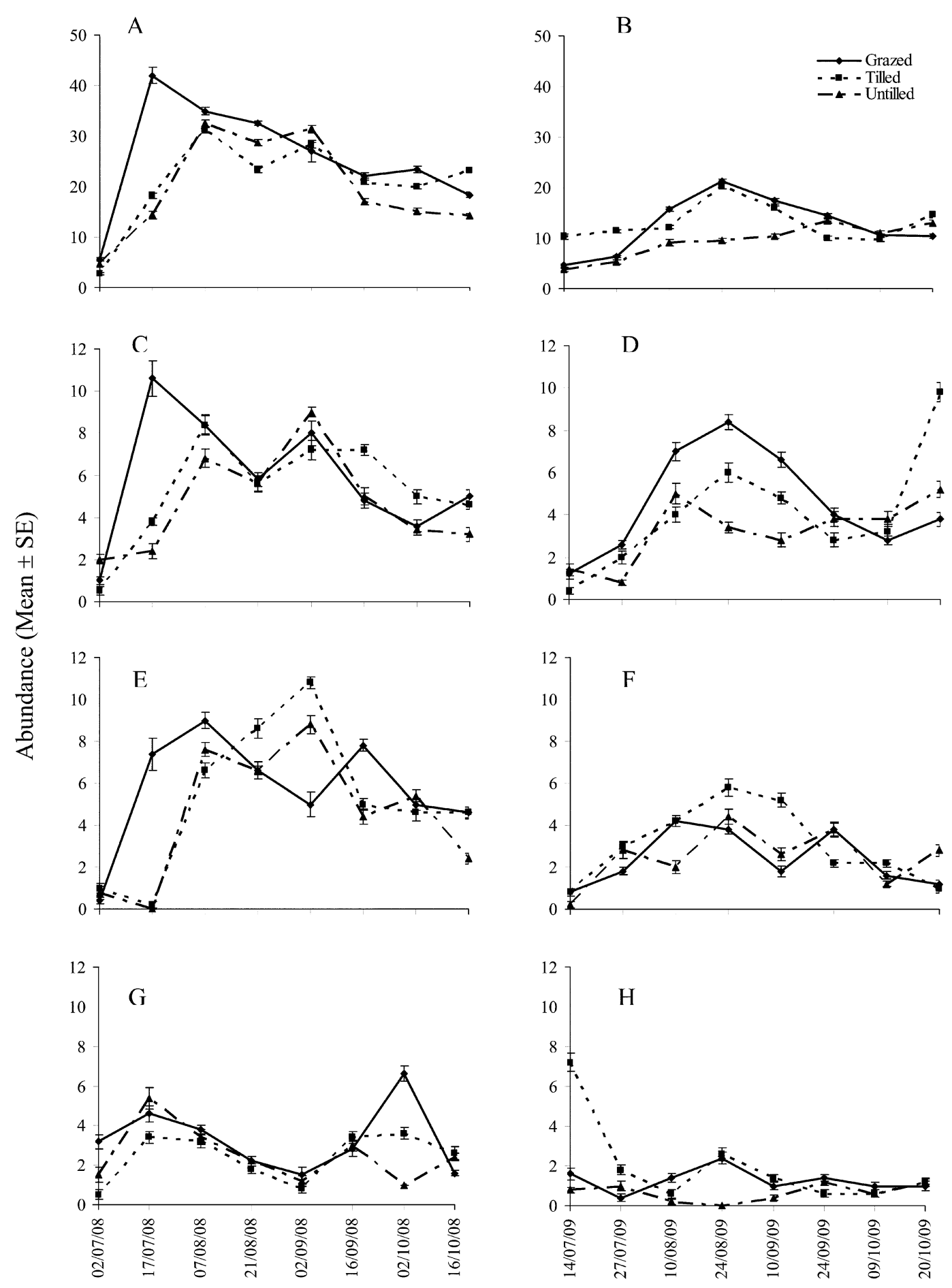

Fig. 1. Seasonal trends in the abundance (mean \pm standard error) of spiders in the two years of the study; $\mathrm{n}=5$. A, B - total spiders; C, D - Philodromidae; E, F - Araneidae; G - Linyphiidae and H - Thomisidae.

Salticidae in tilled grove. There were statistically significant differences in the total abundance of spiders in the untilled (442 individuals) and other two groves $(575,582$ individuals, respectively; $\mathrm{F}_{2,117}=3.94, \mathrm{P}=0.02$ ). The genera Araniella and Oxyopes sp. were more abundant in the grazed grove.

In both years, Anyphaenidae were less abundant in the untilled grove and similarly abundant in the two other groves. Uloboridae were not recorded in the grazed grove.
In 2008, the diversity of spider families was greatest in the tilled grove with 13 families, followed by the untilled with 11 and grazed with 10 families. In contrast, in 2009, there were 12 families in the grazed and untilled groves and 11 families in the tilled grove.

The seasonal trends in the abundance of all the spiders collected and of the most abundant families recorded in each year of the study are shown in Fig. 1. In 2008, the peak of abundance occurred on the $17^{\text {th }}$ of July in the grazed grove and three weeks later in the tilled and 

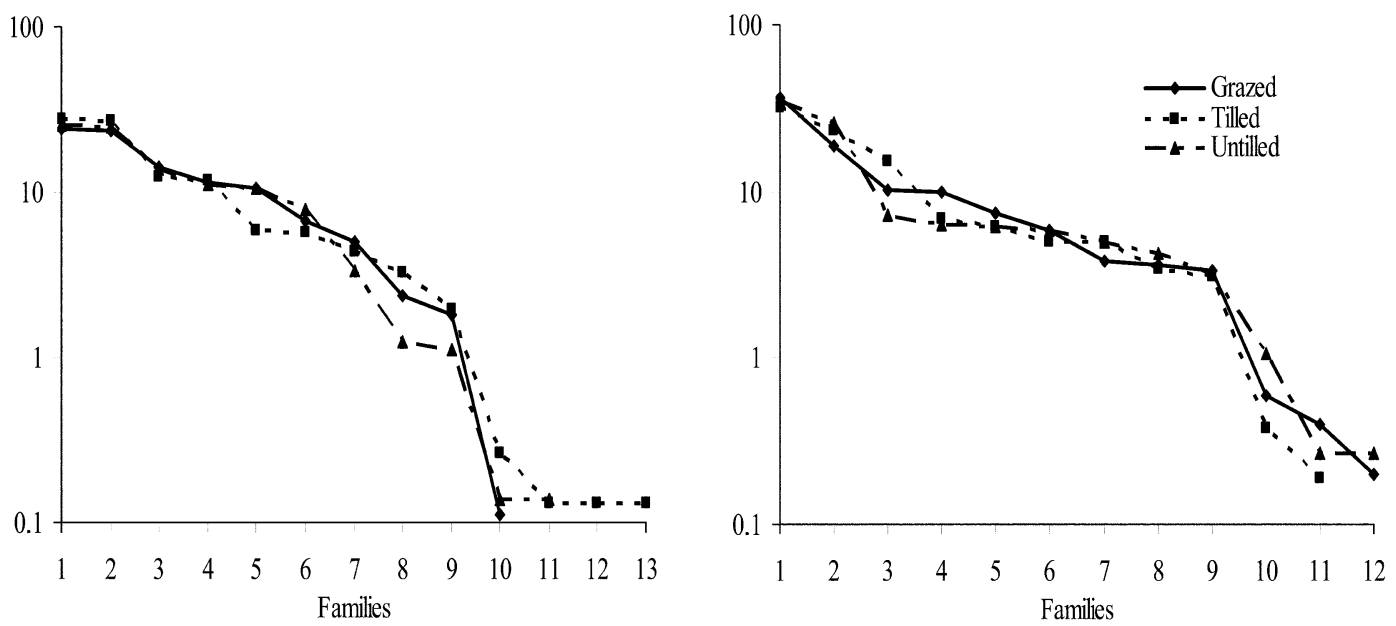

Fig. 2. Rank-abundance curves of the families present in each type of chestnut grove in (A) 2008 and (B) 2009.

untilled groves. In 2009, the mean abundance at each sampling period was lower than that recorded in 2008. The peak of abundance occurred on the $24^{\text {th }}$ of August in the grazed and tilled groves and one month later in the untilled grove. In general, the peaks of abundance of the most abundant families occurred between the middle of July and the end of September. Statistically significant differences between untilled and tilled groves were found only for Thomisidae $(\mathrm{P}=0.02)$.

The best fit to the rank-abundance curves was provided by the broken-stick model for the grazed grove in both years of the study $\left(\chi^{2}=4.19 ; \mathrm{P}=0.94\right.$ in 2008 and $\chi^{2}=$ $9.67 ; \mathrm{P}=0.47$ in 2009 ) while for the tilled grove it was the deterministic model of log-series distribution $\left(\chi^{2}=\right.$ $10.20 ; \mathrm{P}=0.42$ in 2008 and $\chi^{2}=9.50 ; \mathrm{P}=0.49$ in 2009) (Fig. 2). However, data from the untilled grove followed different distributions in each of the years - the brokenstick model in $2008\left(\chi^{2}=11.46 ; \mathrm{P}=0.32\right)$ and log-series model in $2009\left(\chi^{2}=13.69 ; \mathrm{P}=0.19\right)$.

\section{DISCUSSION}

Over the two years of this study, 15 families of spiders were found in the canopies of the chestnut trees, 13 of them in 2008 and 14 in 2009, of which Philodromidae, Araneidae, Thomisidae, Lyniphiidae, Dictynidae and Theridiidae were the most abundant. In Japan, Nakamura \& Nakamura (1977) found a total of 17 families of spiders in the canopy of Japanese chestnut trees, Castanea crenata Sieb. et Zucc., which in composition are similar to that recorded here for communities in Portugal. Namely, the families Philodromidae, Thomisidae and Lyniphiidae were also the most abundant in the canopies of Japanese chestnut.

In every grove, the most abundant genus was Araniella spp. (among the identifiable individuals) and this can be related to their arboreal habits since they build small usually eccentric webs at heights greater than $1.5 \mathrm{~m}$ (Jones, 2004). The dominance of Araniella in the canopy is significant in terms of biocontrol because of the high pest predation/killing rate recorded for these spiders in agroecosystems (Kajak, 1978; Wyss et al., 1995).
The presence of the other families is, despite variations in their relative abundances, in agreement with the results of other studies carried out in this region on crops such as cotton (Pérez-Guerrero et al., 2009), almond (BenhadiMarín et al., 2011), olive (Cárdenas, 2008), and citrus (Barrientos et al., 2010).

As reported for citrus (Barrientos et al., 2010) and almond tree canopies (Benhadi-Marín et al., 2011), there was a very high proportion of immature individuals in the canopies of the chestnut trees. This may be due to collecting complete nests when sampling or the dispersion of immature to new feeding places (Draney, 1997). The great number of unidentified immature specimens could result in an underestimate of the spider species richness in this habitat. To overcome this problem, metabarcoding seems to be a promising tool for assessing in a more reliable and comprehensive way the biodiversity of arthropods (Yu et al., 2012). Apart from family richness, it is worth recording the guild diversity in chestnut tree canopies. According to the system proposed by Uetz et al. (1999), spiders belonging to eight feeding/hunting strategies were present in the canopy of the chestnut trees and were in order of importance: (1) ambushers, (2) orb weavers, (3) space web builders, (4) wandering sheet/ tangle weavers, (5) stalkers, (6) foliage runners, (7) ground runners and (8) sheet web builders. As predators, spiders can be useful biological control agents in agroecosystems. Previous studies show that small linyphiids feed on aphids (Nyffeler \& Sunderland, 2003) and theridiids on small insects (Pekár, 2000). On the other hand, philodromids and thomisids directly hunt bigger insects such as cicadelids (Wisniewska \& Prokopy, 1997) and moths (Ramos \& Lanfranco, 2010) and other web-weaving species preferentially feed on Diptera (Pekár et al., 2011). Therefore, the occurrence of diverse families with different hunting strategies and feeding preferences can contribute to the biocontrol of phytophagous insects that attack chestnut trees, mainly Cydia spp. In Trás-osMontes, the peak of abundance of adults of this pest occurs from the end of August to the middle of September; adults lay their eggs in the leaves closest to the spiny 
cupules of the developing chestnuts and the peak abundance of eggs occurs at the end of September and beginning of October. Shortly after egg hatch the larvae penetrate into the fruit, where they remain until pupation. Thus, the peak of abundance of the most abundant spider families coincides with the period of greatest vulnerability of this pest, which is from the end of August to the beginning of October. This seasonal co-occurrence is an advantage and may favour natural predation of Cydia spp. by spiders.

In both years of the study, the lowest abundance of spiders was recorded in the untilled grove; but, only in 2009 , was it statistically significantly less in the untilled than the other two groves. Several families contributed to this result, namely Philodromidae, Thomisidae, Araneidae, Oxyopidae and Dictynidae, which were all less abundant in the untilled grove. Thus, it seems that the vegetation on the ground is an important habitat for these groups. When soil cover is removed by tillage or frequently disturbed by grazing, spiders tend to climb the trunks of trees in search of a new habitat. Moreover, Philodromidae and Thomisidae are ambush spiders and we suggest that the differences recorded can be explained in terms of resource availability since a tilled soil represents a decrease in the availability of potential prey (e.g. cicadelids) and an increase risk of exposure to potential predators. Araneidae are orb-weavers and need to have a suitable vegetation structure to build their webs, which is less likely to be present in tilled or grazed groves. Oxyopidae are usually found on shrubs and weeds where they hunt during the day and use the upper part of the plant to make and guard their nests (Jones, 2004), thus, as in the grazed grove, where weeds are periodically removed the canopy becomes the only strata with suitable resources. Something similar may apply to Dictynidae, which includes spiders that occupy ground level strata (e.g. Lathys, Argenna and Altella) or are plant-dwellers (e.g. Dictyna and Nigma) occurring both on weeds, as well as higher up on shoot apices of shrubs or foliage of trees (Lissner, 2011).

The rank-abundance curves of the grazed grove in both years of the study and of the untilled grove in 2008 were best fitted by the broken stick model. This model reflects the uniform use of resources by the species in the community and the coexistence of different species can be explained by their use of different niches. The availability of more vertical strata can promote a more even organization of the different taxa according to their habits and therefore, the different guilds are distributed throughout the available space, which reduces inter- and intraspecific competition and results in a more diverse community (Tretzel, 1955; Uetz, 1977). On the other hand, the results for the tilled grove were best fitted by the logarithmic series. In this case, the chestnut canopy is a stable habitat in which the spiders can establish ecological relationships. According to this, in both years of the study, Philodromidae, Thomisidae and Anyphaenidae were less abundant in the canopies of the trees in the untilled than in those of the tilled grove, suggesting that wandering/ runner spiders used lower strata when available. The usefulness of rank abundance curves has been discussed and in particular, Beck \& Chey (2006) point out that this approach can be problematic when discriminating communities according to habitat type because several variables are potentially important in influencing community composition.

In conclusion, soil management affected the abundance of spiders in the canopies of the trees, but the effects were rather weak and not always significant. Tilling the ground may result in a slight increase in the abundance of spiders in the canopy. This may be beneficial for biocontrol, however the negative consequences of these practices in terms of nutrient loss, fertility reduction and erosion, are possibly greater than the advantages resulting from any increase in natural enemy populations. Thus, considering the effect of soil management practices on spider abundance, it would be preferable to maintain soil covered with vegetation (either controlled by grazing or superficially cut before harvest) in order to prevent soil erosion.

ACKNOWLEDGEMENTS. This study was funded by INTERREG III-A, project "PIREFI: Estudios sobre protección integrada y recursos fitogenéticos en cultivos tradicionales de las regiones de Trás-os-Montes y Castilla y León".

\section{REFERENCES}

Aguin-Pombo D., Arraiol A., Franquinho Aguiar A.M., FreITAS E. \& ANGeli G. 2008: Large infestation of chestnuts by Cydia moths in Madeira Island: monitorization of Cydia splendana populations with pheromone lures. - Acta Hortic. 784: 175-180.

Assunção A. 1997: Pragas da castanha. Ficha Técnica no 56. Estação Experimental de Vitivinicultura e Fruticultura. Direcção Regional de Entre Douro e Minho. 2 pp.

Barrientos J.A., Villalba M., Alvis-Dávila L. \& García-Marí F. 2010: Identificación y abundancia de arañas (Araneae) en los cultivos de cítricos valencianos. - Bol. Sanid. Vegetal. Plagas 36: 69-85.

BeCK J. \& Chey V.K. 2006: Are rank-abundance distributions a useful tool of assemblage discrimination in tropical moths? Acta Zool. Sin. 52: 1148-1154.

Benhadi-Marín J., Pereira J.A., Barrientos J.A., Bento A. \& SAnTos S.A.P. 2011: Diversity of predaceous arthropods in the almond tree canopy in Northeastern Portugal: A methodological approach. — Entomol. Sci. 14: 347-358.

Blake S., Foster G.N., Eyre M.D. \& Luff M.L. 1994 Effects of habitat type and grassland management practices on the body size distribution of carabid beetles. - Pedobiologia 38: 502-512.

CÁRdEnAS M. 2008: Análisis de la actividad ecológica de las arañas en el agroecosistema del olivar. $\mathrm{PhD}$ thesis. University of Granada, $318 \mathrm{pp}$.

Cole L.J., McCracken D.I., Downie I.S., Dennis P., Foster G.N., Waterhouse A., Murphy K.J., Griffen A.L. \& KenNEDY M.P. 2005: Comparing the effects of farming practices on ground beetle (Coleoptera: Carabidae) and spider (Araneae) assemblages on Scottish farmland. - Biodivers. Conserv. 14: 441-460.

Cole L.J., Pollock M.L., Robertson D., Holland J.P, MCCRACKEN D.I. \& Harrison W. 2010: The influence of finescale habitat heterogeneity on invertebrate assemblage structure in upland semi-natural grassland. - Agr. Ecosyst. Environ. 136: 69-80. 
Dennis P., Young M.R. \& GoRdon I.J. 1998: Distribution and abundance of small insects and arachnids in relation to structural heterogeneity of grazed, indigenous grasslands. - Ecol. Entomol. 23: 253-266.

DRANEY M.L. 1997: Ground-layer spider (Araneae) of a Georgia piedmont floodplain agroecosystem: species list, phenology and habitat selection. - J. Arachnol. 25: 333-351.

Edwards C.A. 1977: Investigations into the influence of agricultural practice on soil invertebrates. - Ann. Appl. Biol. 87: 515-520.

Ghavami S. 2008: The potential of predatory spiders as biological control agents of cotton pests in Tehran provinces of Iran. - Asian J. Exp. Sci. 22: 303-306.

Greenstone M.H. \& Shufran K.A. 2003: Spider predation: species specific identification of gut contents by polymerase chain reaction. - J. Arachnol. 31: 131-134.

Harwood J.D., Phillips S.W., Lello J., Sunderland K.D., Glen D.M., Bruford M.W., Harper G.L. \& Symondson W.O.C. 2009: Invertebrate biodiversity affects predator fitness and hence potential to control pests in crops. - Biol. Contr. 51: 499-506.

Jones D. 2004: Guía de campo de los arácnidos de España y Europa. Omega, Barcelona, 368 pp.

KAJAK A. 1978: Analysis of consumption by spiders under laboratory and field conditions. - Ekologia Polska 26: 409-427.

Lissner J. 2011: Spiders of Europe and Greenland. Images and Species Descriptions. Available at http://www.jorgenlissner. $\mathrm{dk} /$ Salticidae.aspx. [Accessed: 01/10/2012].

MagurRan A.E. 2004: Measuring Biological Diversity. Blackwell, Malden, MA, $256 \mathrm{pp}$.

Martins A., Linhares I., Raimundo F., Coutinho J.P., GomesLaranjo J., Borges O. \& Sousa V. 2005: The importance of deep soil layers to supply water to agro-forestry systems: a case study of a mature chestnut orchard in Northern Portugal. - Acta Hortic. 693: 663-670.

Monteiro M.L. 2000: Trás-os-Montes um lugar de Castanheiros. In Pereira R. (ed.): Florestas de Portugal. Direcção Geral das Florestas, Lisboa, $255 \mathrm{pp}$.

Monzó C., Mollá Ó., Castañera P. \& Urbaneja A. 2009: Activity-density of Pardosa cribata in Spanish citrus orchards and its predatory capacity on Ceratitis capitata and Myzus persicae. - BioControl 54: 393-402.

Morris T., Symondson W.O.C., Kidd N.A.C. \& CAmpos M. 1999: Las arañas y su incidencia sobre Prays oleae en el olivar. - Bol. Sanid. Vegetal. Plagas 25: 475-489.

NaKamura M. \& Nakamura K. 1977: Population dynamics of the chestnut gall wasp, Dryocosmus kuriphilus Yasumatsu (Hymenoptera: Cynipidae) V. Estimation of the effect of predation by spiders on the mortality of imaginal wasps based on the precipitin test. - Oecologia 27: 97-116.

Nentwig W. \& Wissel C. 1986: A comparison of prey lengths among spiders. - Oecologia 68: 595-600.

Nentwig W., Blick T., Gloor D., HängGi A. \& Kropf C. 2011: Spiders of Europe. (v.6) Available at: www.araneae.unibe.ch. [accessed: 2/10/2011].

Nyffeler M. \& Sunderland K.D. 2003: Composition, abundance and pest control potential of spider communities in agroecosystems: a comparison of European and US studies. - Agr. Ecosyst. Environ. 95: 579-612.

Oelbermann K. \& Scheu S. 2009: Control of aphids on wheat by generalist predators: effects of predator density and the presence of alternative prey. - Entomol. Exp. Appl. 132: $225-231$

Oliveira A.B. 2011: Guia dos produtos fitofarmacêuticos Lista dos produtos com venda autorizada. Ministério da Agri- cultura, do Desenvolvimento Rural e das Pescas - Direção Geral de Agricultura e Desenvolvimento Rural, 222 pp. Available at http://www.dgadr.pt/docs_pdf/GUIA_2011/ GPF_2011_SITE [in Portuguese] [Accessed: $2 / 10 / 2012]$.

Paparatti B. \& Speranza S. 2005: Management of chestnut weevil (Curculio spp.), insect key-pest in Central Italy. Acta Hortic. 693: 551-555.

PekÁr S. 2000: Webs, diet, and fecundity of Theridion impressum (Araneae, Theridiidae). - Eur. J. Entomol. 97: 47-50.

Pekár S., Coddington J.A. \& Blackledge T.A. 2011: Evolution of stenophagy in spiders (Araneae): evidence based on the comparative analysis of spider diets. - Evolution 66: 776-806.

Pérez-Guerrero E., Tamajón R., Aldebis H.K. \& VargasOsuna E. 2009: Comunidad de arañas en cultivos de algodón ecológico en el sur de España. - Revta Colomb. Entomol. 35: $168-172$.

Platnick N.I. 2012: The World Spider Catalog. (v. 12.5). American Museum of Natural History, Available at http://research.amnh.org/iz/spiders/catalog. DOI: 10.5531/db. iz.0001 [accessed: 24/7/2012].

Prieto-Benitez S. \& Méndez M. 2011: Effects of land management on the abundance and richness of spiders (Araneae): A meta-analysis. - Biol. Conserv. 144: 683-691.

Ramos M. \& Lanfranco D. 2010: El complejo de parasitoides de la polilla del brote del pino en Chile: pasado, presente y posible escenario futuro. - Bosque 31: 100-108.

ROBERTS M. 1985: The Spiders of Great Britain and Ireland. Atypidae to Theridosomatidae. Vol. 1. Harley Books, Colchester, Essex, 229 pp.

RoBerts M.J. 1987: The Spiders of Great Britain and Ireland. Linyphiidae. Vol. 2. Harley Books, Colchester, Essex, 204 pp.

Rodríguez E., Fernández-Anero F.J., Ruiz P. \& Campos M. 2006: Soil arthropod abundance under conventional and no tillage in a Mediterranean climate. - Soil Till. Res. 85: 229-233.

SAMu F. \& Bíró Z. 1993: Functional response, multiple feeding and wasteful killing in wolf spider (Araneae: Lycosidae). Eur. J. Entomol. 90: 471-476.

Simon E. 1914-1937: Les Arachnides de France. Sinopsis générale et catalogue des espèces françaises de l'ordre Araneae. Vol. VI. Roret-Mulot, Paris, 1298 pp.

Sunderland K.D., Fraser A.M. \& Dixon A.F.G. 1986: Field and laboratory studies on money spiders (Linyphiidae) as predators of cereal aphids. - J. Appl. Ecol. 23: 433-447.

TRETZEL E. 1955: Intragenerische Isolation und interspezifische Konkurrenz bei Spinnen. - Z. Morphol. Ökol. Tiere 44: 43-162.

Uetz G.W. 1977: Coexistence in a guild of wandering spiders. —J. Anim. Ecol. 46: 531-541.

Uetz G.W., Halaj J. \& Cady A. 1999: Guild structure of spiders in mayor crops. - J. Arachnol. 27: 270-280.

WisniewsKa J. \& Prokopy R.J. 1997: Do spiders (Araneae) feed on rose leafhopper (Edwardsiana rosae; Auchenorrhyncha Cicadellidae) pests of apple trees? - Eur. J. Entomol. 94: 243-251.

Wyss E., Niggli U. \& Nentwig W. 1995: The impact of spiders on aphid populations in a strip-managed apple orchard. $-J$. Appl. Entomol. 119: 473-478.

Yu D.W, Ji Y., Emerson B.C., Wang W., Ye C., Yang C. \& DING Z. 2012: Biodiversity soup: metabarcoding of arthropods for rapid biodiversity assessment and biomonitoring. Methods Ecol. Evol. 3: 613-623.

Received November 1, 2012; revised and accepted February 13, 2013 